\title{
Editors’ Notes
}

\section{EDITORS’ REPORT, SEPTEMBER 2009}

Senior editors get only two shots at the annual report, and by the time their second one bursts into print, they are headed out the door and thinking of what they have achieved and of what remains to do. So what has this editor accomplished during his turn at the helm and, more important, what is left undone?

Accomplishments are not lacking, but the credit is probably due to JOURNAL's staff and the other coeditors. To start with, Jeremy Atack, Sue Isaac, and our Production Editor, Sabrina Boschetti, all played a major role in setting up our online submission system, MS Central, which now stores all of our files and saves an enormous amount of editorial and staff time by automating tasks such as correspondence and the gathering of statistics needed for annual reports. It is far better than the old system the editors had cobbled together, and the only real worry is making sure that incoming editors know MS Central well. Price Fishback, who will take over as senior editor on July 1, is already familiar with its workings, and I will make sure that the same holds for Jean-Laurent Rosenthal, who will succeed me at the office that takes care of the world outside the Americas. Alan Miller, who will be continuing as book review editor at that office, is a veteran of MS Central, and Paul Rhode will have mastered it too. Sabrina Boschetti can provide expert advice about MS Central after I have stepped down, and future staff members and editors can cut their teeth using an online tutorial at the MS Central web site. Future transitions as editors change and the editorial offices move should therefore be easy.

The JOURNAL has also made progress in getting more of its articles listed in the RePEc (Research Papers in Economics) database. Members of the Economic History Association had complained that only recent articles appeared there, but now the coverage extends back to 1981 and will reach even further back in the future. Here thanks are owed our publisher, Cambridge University Press, which provided RePEc with the necessary information. Cambridge also deserves our thanks for giving readers digital access to every article the JOURNAL has ever published. The articles are reproduced as high-resolution, searchable PDFs; details can be found at http://journals.cambridge.org/action/displaySpecialPage?pageId=1548.

If MS Central is now freeing up the editors' time, they can devote more attention to profitable but labor-intensive tasks such as editing papers or suggesting how authors might revise promising but imperfect manuscripts. Yet it might also be worthwhile to exert a bit more effort at recruiting top-notch manuscripts. Last year there was no such need, for the JOURNAL had received a record number of submissions: 203 in all, of which 158 were new. But this year submissions (131 total submissions, 91 of them new) have dropped back to numbers more consistent with the long-term trend (Figure 1).

The temporary jump in submissions may stem from our switching to an online submission system, for Cambridge University Press reports that other journals that have gone on line have also seen submissions surge and then recede. And the JOURNAL is not short of quality manuscripts - far from it. Our backlog between final acceptance and appearance in print was actually a bit too long earlier this year: it had stretched to over a year, in part because of the large of submissions in 2007-2008 and in part because our page constraint had limited us to 28 articles in

\footnotetext{
${ }^{1}$ The Cambridge University Press archive still lacks certain parts of volumes $1-40$ of the JOURNAL, and they are eager for help in finding them. If you can assist them, please contact Gavin Swanson at the Cambridge University Press web site or the JouRNAL's editorial offices.
} 
2008, instead of the usual 30. (We will have partially atoned for the smaller number of articles appearing in 2008 by publishing one additional article in the December 2009 issue.) But we have now worked the backlog down to seven months, which is a bit short of the ideal. That is an additional reason to believe that the editors ought to spend time a little more time scouting for promising manuscripts.

What sort of manuscripts should they look for? Excellent ones obviously, but in my view the JOURNAL could try to attract quality submissions in three areas:

- Works in political economy by political scientists. There is a long tradition here, for one of our most cited articles - the Douglass C. North and Barry R. Weingast's "Constitutions and Commitment: The Evolution of Institutional Governing Public Choice in Seventeenth-Century England." This JouRnAL 49 (1989): 803-32-is coauthored by a political scientist, and the methods political scientists use (particularly those who do empirical work or who have been trained in rational choice political science) are compatible with economics. Political science also has a long tradition of first rate historical research, and political scientists work on questions of interest to economic historians. We in fact published such an article (on the economics of voting for Hitler) in December 2008, and it has already attracted attention. ${ }^{2}$

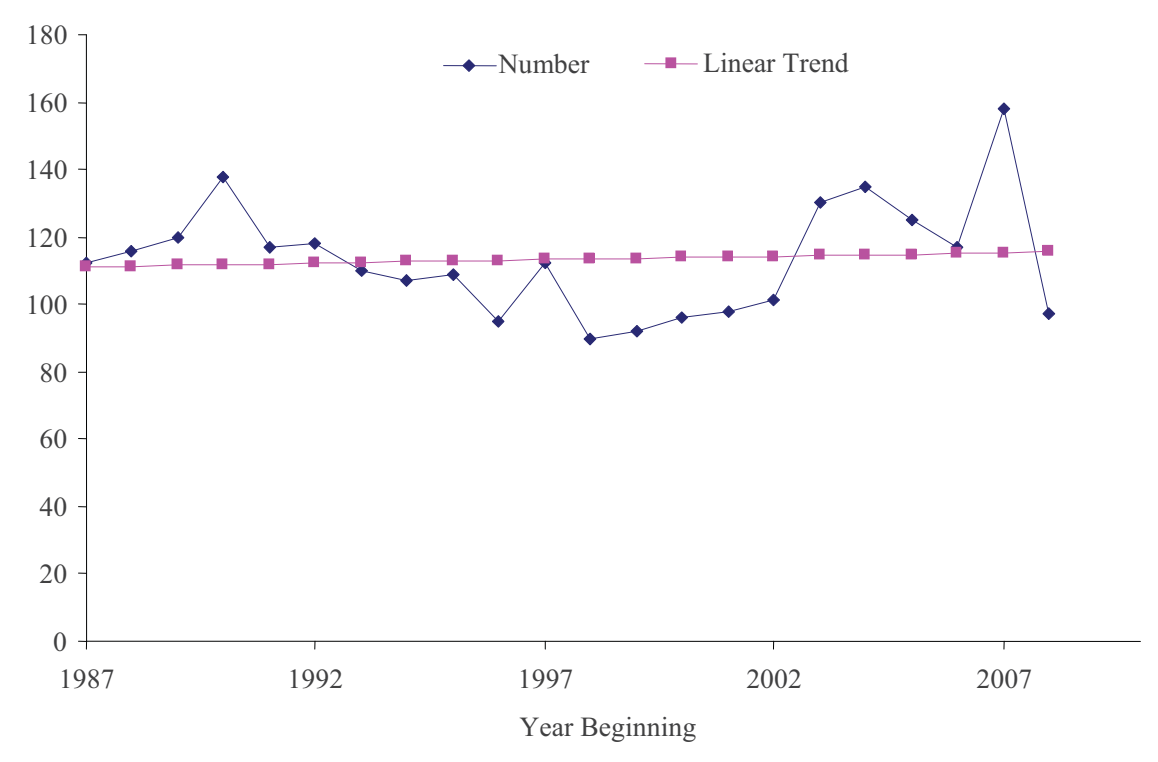

FIGURE 1

TREND IN NEW SUBMISSIONS, 1987/88-2008/09

Source: The yearly totals were taken from the published Editors' Notes.

${ }^{2}$ Gary King, Ori Rosen, Martin Tanner, and Alexander F. Wagner, "Ordinary Economic Voting Behavior in the Extraordinary Election of Adolf Hitler." This JouRNAL 68 (2008): 95196. For the attention it has attracted, see "Who Voted for Hitler?" Wilson Quarterly (Summer 2009): 77-78. 
- Articles that apply theory to large questions of economic history. Although the JOURNAL tends to specialize in empirical work, occasional pieces with a more theoretical bent would be worth pursuing, if the theory actually offered fresh insights and the history were well done, and not just a selective sample of stylized facts. Making room for such articles could also bring us well-known authors whose research draws upon history and who might in turn attract readers from outside economic history itself. That in turn could help build ties to other subfields of economics such as growth theory, development economics, political economy, or law and economics. It could also raise the visibility of the JOURNAL in economics itself. A recent study shows that the JOURNAL has more impact than any other competitor in economic history, and it is the only journal in economic history with significant citation count in mainstream economics publications. But that citation count is still low. ${ }^{3}$

- Pieces by historians on sources or questions of global history. The submissions to encourage here might be notes rather than articles, but they could point out sources that economic historians could use and raise issues in global history where economic historians have a comparative advantage since they have tools for economics. Submissions of this sort might also help attract historians to the JOURNAL.

Again, scouting for manuscripts does not mean lowering our standards. It is an opportunity, and one that I hope future editors will pursue.

Fortunately, the next two editors will have a great deal of help should they decide to take on this challenge. Besides Sabrina Boschetti, and Brendan Livingston, who is an experienced Assistant Editor at the Arizona office, there is a strong editorial board. Although Howard Bodenhorn, Timothy Guinnane, Michael Haines, and Carolyn Moehling are all stepping down from the editorial board after having helped immensely with refereeing, we have five excellent economic historians who will take their place: Karen Clay (Carnegie Mellon), Sumner La Croix (Hawaii), Oscar Gelderblom (Utrecht), Jochen Streb (Hohenheim), and Werner Troesken (Pittsburgh).

What about the pattern of submissions to the two editorial offices? The number of submissions is, to repeat, lower this year, and there were also some shifts in the subject matter of the papers that authors submitted (Table 1). The biggest change was the drop-off in manuscripts on political economy; industry also suffered as a topic. Labor, growth, and trade remained popular, although the number of labor papers did shrink at the Americas office. If we look at the regions covered (Table 2), the number of papers on Asia fell off sharply, and manuscripts devoted to the United States and Canada retreated more than other submissions. As far as time periods are concerned (Table 3), we had some additional manuscripts on earlier periods, and far fewer unclassified submissions. All of these statistics have to be taken with a grain of salt, however, because with MS Central the authors themselves are now classifying papers by topic, region, and period. In the past, that was the editors' job.

The acceptance rate was lower this year than in the past: 11 percent of new and revised manuscripts were accepted this year, versus 19 percent last year (Table 4). The acceptance rate at the American office ( 7 percent) was below that at the Rest of the World office (14 percent), and both seemed low by recent standards (14 percent in the Americas office in 2007-2008, and 27 percent in 2006-2007; 23 percent in the Rest of the World office in 2007-2008, and 14 percent in 2006-2007). ${ }^{4}$

\footnotetext{
${ }^{3}$ Gianfranco Di Vaio and Jacob Weisdorf. "Ranking Economic History Journals: A Citation-Based Impact-Adjusted Analysis." Cliometrica (forthcoming).

${ }^{4}$ The figures here and in the tables do not include conditionally accepted papers. As the report last year explained, all of our acceptances are now conditional until the manuscript is ready to go into
} 
TABLE 1

ARTICLE SUBMISSIONS BY WORLD AREA, BROKEN DOWN BY TOPIC, JULY 2006-JUNE 2009

\begin{tabular}{|c|c|c|c|c|c|c|}
\hline \multirow[b]{2}{*}{ Topic } & \multicolumn{2}{|c|}{ July 2006-June 2007} & \multicolumn{2}{|c|}{ July 2007-June 2008} & \multicolumn{2}{|c|}{ July 2008-June 2009} \\
\hline & $\begin{array}{l}\text { North } \\
\text { America }\end{array}$ & $\begin{array}{l}\text { Rest of } \\
\text { the } \\
\text { World }\end{array}$ & $\begin{array}{l}\text { North \& } \\
\text { South } \\
\text { America }\end{array}$ & $\begin{array}{l}\text { Rest of } \\
\text { the } \\
\text { World }\end{array}$ & $\begin{array}{l}\text { North \& } \\
\text { South } \\
\text { America }\end{array}$ & $\begin{array}{l}\text { Rest of } \\
\text { the } \\
\text { World }\end{array}$ \\
\hline Agriculture & 1 & 3 & 4 & 4 & 3 & 2 \\
\hline Demography & 0 & 3 & 1 & 2 & 4 & 2 \\
\hline Growth & 0 & 14 & 3 & 10 & 4 & 8 \\
\hline History of thought & 0 & 3 & 1 & 1 & 0 & 0 \\
\hline Industry & 5 & 1 & 10 & 6 & 3 & 2 \\
\hline $\begin{array}{l}\text { International trade, } \\
\text { finance }\end{array}$ & 0 & 5 & 3 & 9 & 6 & 4 \\
\hline Labor & 12 & 5 & 20 & 11 & 10 & 11 \\
\hline Money and macro & 10 & 7 & 6 & 6 & 5 & 3 \\
\hline Political economy & 6 & 24 & 14 & 14 & 0 & 5 \\
\hline $\begin{array}{l}\text { Private finance, } \\
\text { capital markets }\end{array}$ & 0 & 15 & 3 & 7 & 7 & 1 \\
\hline Public finance & 0 & 0 & 2 & 0 & 2 & 1 \\
\hline Technology & 0 & 0 & 6 & 3 & 2 & 3 \\
\hline Urban and regional & 0 & 1 & 2 & 0 & 2 & 1 \\
\hline Other & 0 & 2 & 4 & 6 & 3 & 3 \\
\hline Total & 34 & 83 & 79 & 79 & 51 & 46 \\
\hline
\end{tabular}

Note: The numbers include new submissions only. The totals equal the number of new submissions received because a paper is classified in only one topic category. Until March of 2008, the North American Editorial Office was responsible for articles on the United States and Canada; thereafter, it took charge of submissions on Latin America too. In the latest year, this Americas office had 67 total submissions, 51 new and 16 resubmitted. The office for the rest of the world had 64 total submissions, 46 new and 18 resubmitted.

TABLE 2

REGULAR ARTICLE SUBMISSIONS BY REGION, 1 JULY-30 JUNE

\begin{tabular}{|c|c|c|c|c|}
\hline \multirow[b]{2}{*}{ Region } & \multicolumn{4}{|c|}{ Submissions } \\
\hline & 2005-2006 & 2006-2007 & 2007-2008 & $2008-2009$ \\
\hline Africa & 3 & 1 & 1 & 4 \\
\hline Asia & 7 & 12 & 17 & 5 \\
\hline Australia and New Zealand & 3 & 2 & 2 & 0 \\
\hline Eastern Europe/Russia & 2 & 4 & 7 & 2 \\
\hline Great Britain & 14 & 16 & 12 & 8 \\
\hline Latin America & 7 & 9 & 9 & 8 \\
\hline Middle East & 5 & 2 & 6 & 3 \\
\hline Non-Spanish speaking Caribbean & 0 & 0 & 0 & 1 \\
\hline United States and Canada & 57 & 38 & 72 & 38 \\
\hline Western Europe & 38 & 44 & 43 & 26 \\
\hline Not applicable & 5 & 5 & 9 & 2 \\
\hline
\end{tabular}

Note: The numbers include new submissions only. Totals exceed new submissions because a paper can be classified as pertaining to more than one region.

production. Getting some manuscripts into production does sometimes involve considerable editing. 
TABLE 3

REGULAR ARTICLE SUBMISSIONS BY PERIOD, 1 JULY-30 JUNE 2006-2007, 2007-2008, AND 2008-2009

\begin{tabular}{lccc}
\hline \hline \multirow{1}{*}{\multicolumn{1}{c}{ Period }} & \multicolumn{3}{c}{ Submissions } \\
\cline { 2 - 4 } & $2006-2007$ & $2007-2008$ & $2008-2009$ \\
\hline Twenty-first century & 1 & 2 & 1 \\
Twentieth century & 57 & 67 & 30 \\
Nineteenth century & 60 & 81 & 38 \\
Seventeenth and eighteenth centuries & 30 & 18 & 15 \\
Pre-seventeenth century & 14 & 13 & 11 \\
Not applicable or unknown & 2 & 30 & 2 \\
\hline
\end{tabular}

Note: The numbers include new submissions only. Totals exceed submissions because a paper can be classified as pertaining to more than one period.

TABLE 4

ACCEPTANCE AND TURNAROUND

\begin{tabular}{|c|c|c|c|c|c|c|}
\hline & \multicolumn{2}{|c|}{ American Office } & \multicolumn{2}{|c|}{$\begin{array}{l}\text { Office for the Rest } \\
\text { of the World }\end{array}$} & \multicolumn{2}{|c|}{ Total } \\
\hline & 2007/08 & 2008/09 & $2007 / 08$ & $2008 / 09$ & $2007 / 08$ & $2008 / 09$ \\
\hline Accepted & 12 & 5 & 27 & 9 & 39 & 14 \\
\hline Revise and resubmit & 26 & 23 & 22 & 20 & 48 & 43 \\
\hline Rejected or withdrawn & 40 & 29 & 59 & 29 & 99 & 58 \\
\hline Not yet decided & 9 & 10 & 8 & 6 & 17 & 16 \\
\hline Total & 87 & 67 & 116 & 64 & 203 & 131 \\
\hline \multicolumn{7}{|l|}{ Decision Lags (in days) } \\
\hline Year & \multicolumn{2}{|c|}{ Minimum } & Maximum & \multicolumn{2}{|r|}{ Mean } & Median \\
\hline \multicolumn{7}{|l|}{ All submissions } \\
\hline $2004 / 2005$ & \multicolumn{2}{|r|}{1} & 366 & \multicolumn{2}{|r|}{112} & 104 \\
\hline $2005 / 2006$ & \multicolumn{2}{|r|}{1} & 338 & \multicolumn{2}{|r|}{97} & 92 \\
\hline $2006 / 2007$ & \multicolumn{2}{|r|}{1} & 215 & \multicolumn{2}{|r|}{88} & 92 \\
\hline $2007 / 2008$ & \multicolumn{2}{|c|}{1} & 216 & \multicolumn{2}{|r|}{72} & 81 \\
\hline $2008 / 2009$ & \multicolumn{2}{|c|}{30} & 193 & \multicolumn{2}{|r|}{88} & 92 \\
\hline \multicolumn{7}{|l|}{ New submissions only } \\
\hline $2004 / 2005$ & \multicolumn{2}{|r|}{1} & 260 & \multicolumn{2}{|r|}{100} & 90 \\
\hline $2005 / 2006$ & \multicolumn{2}{|r|}{1} & 338 & \multicolumn{2}{|r|}{94} & 90 \\
\hline $2006 / 2007$ & \multicolumn{2}{|r|}{1} & 215 & \multicolumn{2}{|r|}{89} & 111 \\
\hline $2007 / 2008$ & \multicolumn{2}{|c|}{1} & 216 & \multicolumn{2}{|r|}{72} & 80 \\
\hline $2008 / 2009$ & \multicolumn{2}{|c|}{31} & 176 & \multicolumn{2}{|r|}{87} & 91 \\
\hline
\end{tabular}

Note: The acceptance figures include new submissions and resubmissions, except when the resubmitted papers have already been accepted conditionally. Until March of 2008, the American Editorial Office was responsible for articles on the United States and Canada; thereafter, it took charge of submissions on Latin America too. 
Mean and median decision lags are slightly higher this year, but certainly within the range of recent experience (Table 4). Although the maximum decision time was lower, the minimum time rose, but a third to a half of the increase may simply reflect the transition to MS Central, which starts counting the number of days a decision takes from the very moment an author submits a paper. In the past, editors usually began counting only when they knew that the author had paid the submission fee or joined the Economic History Association. With MS Central, the editors still wait (there is no point reading a paper or choosing referees if the author does not pay the required fee), but now the clock is ticking relentlessly, and it may tick for 10 days or more while the editorial offices wait for a confirmation from the business office that the author has in fact made payment. The wait could be reduced if the editorial offices could have instant access via an online web site to the EHA membership lists.

The rest of the increase in the minimum decision may be a response to the way MS Central times its reminders to the editors. By shortening that time, we could perhaps cut not just the minimum decision time but all the decision times by perhaps 10 or 15 days. Even without that change, though, the decision lags are extremely short by the standards of most other journals, particularly in economics. That is a strong selling point if we want to attract good papers. Why wait months or more to hear, when the JOURNAL will give you a decision in an average of 87 days?

Book reviews are one final matter that deserve attention. In 2008 the JOURNAL published 46 of them, despite the binding page constraint that limited the number of articles that appeared. Through the June issue of 2009, only 17 have appeared. Fears about the page constraint are a partial explanation, as is the endemic problem of delinquent reviewers, but the page constraint no longer seems to be a worry for 2009 . The editors should therefore push reviewers to get reviews done. Paul Rhode has taken the initiative here and reminded reviewers to get their reviews in, and Alan Miller has followed his lead and created a standard email that can be used by future book review editors.

PhiLIP Hoffman, California Institute of Technology

Referees for the year were:

Brian A'Hearn

Robert C. Allen

Lee J. J. Alston

Manuela Angelucci

Jeremy Atack

Martha Bailey

Fred Bateman

Joerg Baten

Howard Bodenhorn

Dan Bogart

Maristella Botticini

Leah Platt Boustan
George R. Boyer

Timothy Bresnahan

Stephen Broadberry

John Brown

Victor Bulmer-Thomas

Charles Calomiris

Neil Canaday

Linda Carter

Benjamin Chabot

Latika Chaudhary

Gregory Clark

Karen Clay 


\begin{tabular}{|c|c|}
\hline Raymond L. Cohn & Gillian Hamilton \\
\hline William J. Collins & Christopher Hanes \\
\hline Metin Cosgel & Zeynep Hansen \\
\hline Dora Costa & David Harbord \\
\hline Lee A. Craig & C. Knick Harley \\
\hline Tomas Cvrcek & Scott Harrington \\
\hline Guillaume Daudin & Mark Harrison \\
\hline John Devereux & Timothy Hatton \\
\hline Jan de Vries & Michael Haupert \\
\hline Mark Dincecco & Robert Higgs \\
\hline Mauricio Drelichman & Eric Hilt \\
\hline Alan Dye & Paul M. Hohenberg \\
\hline Michael Edelstein & Rick Hornbeck \\
\hline Benjamin Elman & William Horrace \\
\hline Jari Eloranta & Michael Huberman \\
\hline Stanley Engerman & Jeffrey Hummel \\
\hline Rui Esteves & Joseph Inikori \\
\hline Giovanni Federico & Douglas Irwin \\
\hline Stefano Fenoaltea & David Jacks \\
\hline Price Fishback & Charles Kahn \\
\hline Marc Flandreau & Noel D. Johnson \\
\hline Robert Fleck & Ryan Johnson \\
\hline Jorge Flores & Camilla Josephson \\
\hline Roderick Floud & Shawn Kantor \\
\hline Oscar Gelderblom & James Kau \\
\hline Thomas M. Geraghty & Ian Keay \\
\hline Yoshihisa Godo & Amalia Kessler \\
\hline Jessica Goldberg & Gary King \\
\hline Claudia Goldin & Christopher Kingston \\
\hline Regina Grafe & Hebert Klein \\
\hline George W. Grantham & Daniel Klerman \\
\hline Paul Gregory & Timur Kuran \\
\hline Avner Greif & Sumner La Croix \\
\hline Farley Grubb & Naomi R. Lamoreaux \\
\hline Timothy Guinnane & Chulhee Lee \\
\hline Stephen Haber & Tim Leunig \\
\hline Michael Haines & Frank D. Lewis \\
\hline
\end{tabular}




\begin{tabular}{|c|c|}
\hline Gary Libecap & Cormac Ó Gráda \\
\hline Peter Limb & Alan L. Olmstead \\
\hline Peter Lindert & Martha Olney \\
\hline Trevon Logan & Kim Oosterlinck \\
\hline Jason Long & Kevin O'Rourke \\
\hline Anton Lowenberg & Robert Pahre \\
\hline Robert Lusch & Sevket Pamuk \\
\hline Debin Ma & Toni Pierenkemper \\
\hline Jim MacGee & Vicente Pinilla \\
\hline Mary MacKinnon & Gilles Postel-Vinay \\
\hline Patrick Manning & Mark Potter \\
\hline Robert Margo & Leandro Prados de la Escosura \\
\hline Noel Maurer & Jonathan Pritchett \\
\hline Anne E. C. McCants & Thomas G. Rawski \\
\hline Robert McGuire & Angela Redish \\
\hline Christopher Meissner & Claudia Rei \\
\hline Jacob Metzer & Jaime Reis \\
\hline Peter B. Meyer & Paul Rhode \\
\hline Grant Miller & Albrecht Ritschl \\
\hline Kathryn Miller & Hugh Rockoff \\
\hline David Mitch & Nicolas Rodger \\
\hline Kris James Mitchener & Joshua L. Rosenbloom \\
\hline Carolyn Moehling & Jean-Laurent Rosenthal \\
\hline Jon R. Moen & Robert J. Ross \\
\hline Joel Mokyr & Peter Rousseau \\
\hline Petra Moser & Thomas Safley \\
\hline Bernardo Mueller & Cheryl Schonhardt-Bailey \\
\hline John Murray & George Selgin \\
\hline Aldo Musacchio & Andrew Seltzer \\
\hline Steven Nafziger & Carol Hua Shiue \\
\hline Suresh Naidu & Richard Sicotte \\
\hline Larry Neal & Pierre Sicsic \\
\hline Todd C. Neumann & Mark Spoerer \\
\hline Nathan Nunn & Richard H. Steckel \\
\hline Alessandro Nuvolari & Jochen Streb \\
\hline John Nye & Roman Studer \\
\hline Lawrence H. Officer & William Summerhill \\
\hline
\end{tabular}


Nathan Sussman

Richard Sutch

Dhanoos Sutthiphisal

Richard Sylla

Melissa Thomasson

Ross Thomson

Giovanni Toniolo

Jaret Treber

John Treble

William Frank Troost

John Turner

Richard Unger

Patrick Van Horn

Jan Luiten Van Zanden

Francois Velde

Nancy Virts

Hans-Joachim Voth

John Wallis

Patrick Wallis

Kirsten Wandschneider

Warren Weber

Simone Wegge

Marc Weidenmier

Thomas Weiss

Robert Whaples

Warren Whatley

David C. Wheelock

Eugene White

Susan Wolcott

Nikolaus Wolf

Robert Wright 